7. Reprod. Fert. (1967) 13, 337-340

BRIEF COMMUNICATION

\title{
PREVENTION OF COAGULUM FORMATION WITH RECOVERY OF MOTILE SPERMATOZOA FROM RHESUS MONKEY SEMEN
}

\author{
DALE D. HOSKINS AND D. L. PATTERSON \\ Department of Biochemistry, Oregon Regional Primate Research Center, \\ Beaverton, Oregon, U.S.A.
}

(Received 30th September 1966)

The semen of several species of animals including the rat, guinea-pig and rhesus monkey is characterized by a rapid coagulation of ejaculated seminal fluid (Mann, 1964). In the rhesus monkey (Macaca mulatta) this process is usually complete within 1 min with resultant formation of a firm coagulum. Autolysis of this, the so-called vaginal plug, does not take place to an appreciable degree in vitro. Spermatozoa appear to be liberated by an exudation process. Studies in this laboratory have shown that as much as 60 to $70 \%$ of the ejaculated spermatozoa may remain confined in the coagulum after incubation in vitro for $30 \mathrm{~min}$ at $37^{\circ} \mathrm{C}$. The present study was undertaken in order to define conditions for the isolation of motile spermatozoa from freshly ejaculated semen. Semen was collected from seven monkeys ranging in weight from 6 to $10 \mathrm{~kg}$ by the electro-ejaculation technique of Mastroianni \& Manson (1963). Ejaculates averaging 2 to $4 \mathrm{~g}$ were obtained from each animal at approximately 3-day intervals. The motility of spermatozoa was evaluated microscopically by the hanging drop technique.

Efforts were directed toward both the solubilization of the coagulum and the prevention of its formation. All experiments were carried out with hydrolytic enzymes. An initial attempt was made to define a proper washing medium required for the removal of lytic agents. These studies, utilizing exuded spermatozoa, revealed Norman-Johnson's-Solution 1 (Norman, Goldberg, Porterfield \& Johnson, 1960) containing either glucose or fructose, to be a washing and diluting media superior to Ca-free Ringer's solution (Mann, 1946), Ringer's phosphate solution (Mann, 1946), or Ca-free Ringer's solution containing 0.1 N tris-HCl buffer, $\mathrm{pH} 7 \cdot 4$. Similar results have been obtained with human semen by Freund \& Wiederman (1966).

Efforts to obtain motile spermatozoa from freshly coagulated semen by incubation at $37^{\circ} \mathrm{C}$ of diced sections $\left(2\right.$ to $5 \mathrm{~mm}^{3}$ ) with solutions of freshly prepared spermatozoa-free human seminal plasma, viper venom (300 units $/ \mathrm{ml}$ phosphodiesterase), or with $\alpha$-amylase $(0.2$ to $2.0 \%)$ and $\alpha$-chymotrypsin $(0.1$ to $2 \cdot 0 \%$ ) in Norman-Johnson's-Solution $1(\mathrm{~N}-\mathrm{J}-1)$ were, in the main, unsuccessful. 
Solubilization coupled with preservation of a small measure of motility was observed only with chymotrypsin. The enzyme was effective only at concentrations (e.g. $2 \%$ ) which ensured complete solubilization of the coagulum within less than $1 \mathrm{hr}$. Subsequent washing abolished motility. Solubilization of coagulated rhesus monkey semen with recovery of some motile spermatozoa has also recently been described by Rutter, Kerber \& Reese (personal communication).

We wish to stress here that the difficulties encountered in the recovery of motile spermatozoa from the coagulum may be largely circumvented by collecting the ejaculates directly into solutions of hydrolytic enzymes. As shown in Table 1, collection of semen into solutions containing high levels of $\alpha$-chymotrypsin, trypsin, or $\alpha$-protease (obtained from bovine pancreas) in $\mathrm{N}-\mathrm{J}-1$ solution results in the rapid and complete liquefaction of seminal plasma. The

TABLE 1

PREVENTION OR REPRESSION OF COAGULUM FORMATION BY HYDROLYTIC ENZYMES

\begin{tabular}{l|c|c|c|c|c}
\hline \multicolumn{1}{c|}{ Enzyme } & $\begin{array}{c}\text { Enzyme conc. } \\
(\%)\end{array}$ & $\begin{array}{c}\text { Animal } \\
\text { No. }\end{array}$ & $\begin{array}{c}\text { Solubilization } \\
\text { time (min) }\end{array}$ & \multicolumn{2}{|c}{ Motility $\neq$} \\
\cline { 4 - 6 } & $\begin{array}{c}\text { Before } \\
\text { washing }\end{array}$ & $\begin{array}{c}\text { After } \\
\text { washing }\end{array}$ \\
\hline$\alpha$-Chymotrypsin & $0 \cdot 1$ & 1526 & $>360$ & 5 & $\mathbf{- *}^{*}$ \\
& $1 \cdot 0$ & 1504 & 30 & 5 & 4 \\
Trypsin & $2 \cdot 0$ & 2161 & 2 to 3 & 5 & 4 \\
Protease & $2 \cdot 0$ & 1526 & 15 to 30 & 5 & 4 \\
& $2 \cdot 0$ & 2161 & 15 to $30 \dagger$ & 5 & $-*$ \\
\hline
\end{tabular}

* Not measured.

+ Reagglutinated after 30 min.

¥ Motility is based on an arbitrary and subjective scale with values ranging from 0 to 5 . An attempt was made to take into consideration both the presence or absence of motility and the rate of forward progression. A rating of 5 indicates a suspension containing at least 80 to $90 \%$ motile forms showing a rapid rate of forward progression.

spermatozoa so obtained may be subsequently washed with $\mathrm{N}-\mathrm{J}-1$ solution with little loss in motility (cf. Table 2). $\alpha$-Chymotrypsin at the level of $0.1 \%$ used by Freund (1958) for the liquefaction of guinea-pig semen failed to prevent formation of the coagulum. The procedure which has consistently yielded preparations of washed motile spermatozoa containing essentially all the cells present in the ejaculate is detailed as follows. All operations are carried out at $37^{\circ} \mathrm{C}$. Ejaculated seminal fluid is directed into a $20 \mathrm{ml}$ beaker containing $3 \mathrm{ml}$ $2 \% \alpha$-chymotrypsin in $\mathrm{N}-\mathrm{J}-1$ solution (containing $500 \mathrm{mg} \%$ fructose in place of glucose). Care is taken to avoid solidification of semen on the beaker walls. Centres of coagulation are prevented from forming or are dispersed by a rapid agitation of the suspension with a glass stirring-rod. Complete solution is usually obtained within $5 \mathrm{~min}$. The exact solution time, which may vary between 1 and $30 \mathrm{~min}$, is a function of the volume of the ejaculate, the experimental animal used, and the speed with which the initial dispersal is made. Physically, the coagulation process appears to start, to be arrested, and then to be reversed. The suspension is subsequently incubated in a water bath for a total of $30 \mathrm{~min}$ from the time of ejaculation and centrifuged at $700 \mathrm{~g}$ for $5 \mathrm{~min}$. Sedimented spermatozoa are resuspended in a volume of $\mathrm{N}-\mathrm{J}-1$ solution equal to that from which 
they were derived, resedimented, and finally suspended in 1 to $2 \mathrm{ml}$ washing medium. It is estimated that suspensions so obtained contained 2 to $5 \mu \mathrm{g} \alpha$ chymotrypsin $/ \mathrm{ml}$. Before washing, spermatozoa in $\alpha$-chymotrypsin show good motility which is not appreciably diminished on standing at $37^{\circ} \mathrm{C}$ for periods up to $3 \mathrm{hr}$.

A comparison of the motility and viability of washed spermatozoa obtained by the prevention of coagulation with spermatozoa exuded from the formed coagulum during a $30-\mathrm{min}$ period is shown in Table 2. Motility ratings were

TABLE 2

COMPARISON OF MOTILITY AND VIABILITY OF EXUDED AND CHYMOTRYSPIN-TREATED RHESUS MONKEY SPERMATOZOA

\begin{tabular}{c|c|c|c|c}
\hline \multirow{2}{*}{ Animal No. } & \multicolumn{2}{|c|}{ Exuded spermatozoa } & \multicolumn{2}{c}{ Chymotrypsin-treated spermatozoa } \\
\cline { 2 - 5 } & Motility rating $\dagger$ & $\%$ Live* & Motility rating $\dagger$ & $\%$ Live* \\
\hline 491 & $9 / 3$ & 81 & $8 / 4$ & 77 \\
2161 & $9 / 4$ & 86 & $7 / 3$ & 63 \\
1526 & $7 / 3$ & 84 & $7 / 3$ & 66 \\
1504 & $8 / 4$ & 78 & $7 / 3$ & 75 \\
\hline
\end{tabular}

* Values obtained on differential counting of 200 to 300 spermatozoa.

† See text, p. 339 .

based on the system described by Aalbers, Mann \& Polge (1961) in which the upper number refers to the percent/10 of the spermatozoa showing any motility and the lower refers to the percentage showing progressive motility. The latter figure is based on a scale from 0 to 5 with each number representing a span of $20 \%$. Live-dead estimates were based on the procedure described by Swanson $\&$ Bearden (1951). The results shown indicate that the spermatozoa contained in freshly ejaculated rhesus monkey semen may be isolated and washed free from coagulinogenic elements by use of the proteolytic enzyme $\alpha$-chymotrypsin. Spermatozoa so obtained possess a motility and viability comparable to that of exuded spermatozoa.

Recent studies in this laboratory have shown that spermatozoa which are solubilized essentially as described above (the only difference being a shortening of the incubation period with $\alpha$-chymotrypsin to $5 \mathrm{~min}$ ) produce ${ }^{14} \mathrm{C}$-lactate and ${ }^{14} \mathrm{CO}_{2}$ from uniformly labelled ${ }^{14} \mathrm{C}$-fructose at the same rate as normally exuded spermatozoa. The questions whether enzyme-treated spermatozoa retain the respiratory, glycolytic and fertilization capacities of normally exuded spermatozoa are currently under investigation.

Publication No. 195 from the Oregon Regional Primate Research Center, Beaverton, Oregon, supported in part by grant FR 00163 of the National Institutes of Health.

The authors are indebted to Dr Luigi Mastroianni and Mr Charles Meltzer for assistance in demonstrating the electro-ejaculation technique. We would also like to express our appreciation to Mr Don Richert and Mr Henry Stadelman for invaluable technical assistance. This work was supported in part by grant AM 08958-03 of the National Institutes of Health. 


\section{REFERENCES}

Aalbers, J. G., Mann, T. \& Polge, G. (1961) Metabolism of boar semen in relation to sperm motility and survival. 7. Reprod. Fert. 2, 42.

Freund, M. (1958) Collection and liquefaction of guinea pig semen. Proc. Soc. exp. Biol. Med. 98, 538.

Freund, M. \& Wiederman, J. (1966) Factors affecting the dilution, freezing and storage of human semen. J. Reprod. Fert. 11, 1.

ManN, T. (1946) Studies on the metabolism of semen. 3. Fructose as a normal constituent of seminal plasma. Site of formation and function of fructose in semen. Biochem. $7.40,481$.

MANN, T. (1964) The biochemistry of semen and of the male reproductive tract, p. 76. Methuen, London.

Mastroianni, L. \& Manson, W. A. (1963) Collection of monkey semen by electroejaculation. Proc. Soc. exp. Biol. Med. 112, 1025.

Norman, C., Goldberg, E., Porterfield, I. D. \& Johnson, C. E. (1960) Prolonged survival of human sperm in chemically defined media at room temperatures. Nature, Lond. 188, 760.

Swanson, W. W. \& Bearden, H. J. (1951) An eosin-nigrosin stain for differentiating live and dead bovine spermatozoa. F. Anim. Sci. 10. 981 . 